\title{
Temporal profile and clinical significance of serum neuron-specific enolase and S100 in ischemic and hemorrhagic stroke
}

\author{
David Brea, Tomás Sobrino, Miguel Blanco, \\ Iván Cristobo, Raquel Rodríguez-González, \\ Manuel Rodríguez-Yañez, Octavio Moldes, \\ Jesús Agulla, Rogelio Leira and José Castillo* \\ Department of Neurology, Clinical Neuroscience \\ Research Laboratory, Hospital Clínico Universitario, \\ University of Santiago de Compostela, Santiago de \\ Compostela, Spain
}

\begin{abstract}
Background: Neuron-specific enolase (NSE) and S100 protein are implicated in several brain injuries, including stroke. Our objective was to analyze the temporal profile and the clinical significance of NSE and S-100 in acute ischemic (IS) and intracerebral hemorrhage (ICH).

Methods: We studied 224 patients with IS and 44 patients with $\mathrm{ICH}$. Computerized tomography (CT) scans were performed to assess infarct volume. Stroke severity was evaluated using the National Institute of Health Stroke Scale (NIHSS), and functional outcome at 3 months with the modified Rankin Scale (mRS). Serum NSE and S100 protein were measured using an electrochemiluminescenceimmunoassay.

Results: Peak values were found at $72 \mathrm{~h}$ for NSE and at $24 \mathrm{~h}$ for $\mathrm{S} 100$ in IS. For ICH, peak values were found at $24 \mathrm{~h}$ for both NSE and S100. At these time intervals S100 and NSE correlated with the NIHSS score and were independently associated with poor outcome.

Conclusions: High serum NSE and S100 are associated with poor outcome in IS, and high serum NSE is associated with poor outcome in ICH. These findings suggest the potential utility of NSE and S100 as prognostic markers for acute stroke.
\end{abstract}

Clin Chem Lab Med 2009;47:1513-8.

Keywords: acute stroke; neuron-specific enolase; outcome; S100 protein.

\section{Introduction}

In recent years, biochemical markers of brain damage have gained particular attention. The study of molecular markers associated with stroke has proven to be

*Corresponding author: Prof. José Castillo, Servicio de Neurología, Hospital Clínico Universitario, 15706 Santiago de Compostela, Spain

Phone: +34 981951348 , Fax: +34981951098,

E-mail: jose.castillo@usc.es

Received May 6, 2009; accepted August 21, 2009;

previously published online October 28, 2009 useful for both diagnostic and prognostic purposes. Molecular markers of neurotoxicity (1) and inflammation $(2,3)$ have been associated with early neurological deterioration (4), infarct volume, hemorrhagic transformation $(5,6)$ and other clinical variables.

Protein $\mathrm{S} 100$ is a dimeric acidic calcium binding protein whose isoforms $\mathrm{S} 100$ and $\mathrm{S} 100 \mathrm{~A} 1 \beta$ are found predominantly in glial cells and Schwann cells (7-9). This protein performs intracellular functions, such as modulation of cytoskeleton proteins, regulation of cellular cycles, and extracellular functions, all of which are concentration dependent. Neuron-specific enolase (NSE) is the neuronal form of the intracytoplasmic glycolitic enzyme enolase. The $\gamma \gamma$ isoform is found in neurons, as well as in cells with neuroendocrine differentiation. This dimeric enzyme has a molecular weight of $78 \mathrm{kDa}$ and catalyzes the interconversion of 2-phosphoglycerate and phosphoenolpyruvate (10). Since NSE is not secreted physiologically, an increase in serum and cerebrospinal fluid (CSF) concentrations is considered to be a marker for neuronal cell damage. Several studies have been performed to investigate its potential role as a peripheral biochemical marker for neuronal injury involving reactive gliosis, astrocytic death and/or blood-brain-barrier dysfunction (11).

Some studies have found correlation between NSE and $\mathrm{S} 100$ serum values and brain damage following stroke. However, the temporal profile of these biomarkers in serum is not clear because different peak values are found in the literature (12). In addition, there is some controversy regarding the best timepoint for measuring NSE and S100 in serum. Different investigators describe the correlation between these biomarkers and clinical variables using various times (13-19).

We investigated the relationship between the temporal profile of proteins S100 and NSE and their correlation with clinical variables and functional outcome in a large series of patients with ischemic stroke (IS) and intracerebral hemorrhage (ICH).

\section{Materials and methods}

\section{Study population and patients characteristics}

Between May 2004 and September 2005, 355 patients with a first time stroke in the anterior territory of $<12 \mathrm{~h}$ duration, and previously independent with respect to their daily living activities, were prospectively evaluated for inclusion. Patients with chronic inflammatory diseases $(n=7)$, severe hepatic $(n=4)$ or renal $(n=3)$ diseases, hematological diseases $(n=3)$, cancer $(n=5)$, or infectious disease within 
15 days prior to admission $(n=11)$ and patients included in other clinical trials $(n=41)$ were excluded. Five patients did not agree to participate in the study and eight patients were lost to follow-up. Thus, a total of 224 patients (mean age 70.2 years, mean time from onset $7.2 \mathrm{~h}$ ) with IS, and 44 patients (mean age 61.5 years, mean time from onset $4.7 \mathrm{~h}$ ) with $\mathrm{ICH}$ were included.

This study was approved by the Ethics Committee of our hospital and was in accordance with the Helsinki Declaration of 1975 , as revised in 1983. Informed consent was obtained from patients or their relatives.

\section{Clinical variables}

All patients were admitted in the Acute Stroke Unit and treated by the same unit staff according to the Guidelines of the Cerebrovascular Diseases Study Group of the Spanish Society of Neurology (20). Medical history, potential vascular risk factors, blood and coagulation testing, 12-lead ECG, chest radiography, and carotid ultrasonography were performed at admission.

Stroke severity was assessed by a certified neurologist using the National Institute of Health Stroke Scale (NIHSS) at admission, 1, 3, $7 \pm 1$ and $90 \pm 7$ days from onset of symptoms $(21,22)$. Functional outcome was evaluated at 90 days from onset of symptoms using the modified Rankin Scale (mRS) (22).

\section{Neuroimaging studies}

Computerized tomography (CT) scans were performed at admission and between days 4 and 7 of hospitalization. Early CT signs of infarction were evaluated upon admission, and infarct and $\mathrm{ICH}$ volume were assessed using the second CTscan. Infarct and ICH volume were calculated using the radiographic plate with the formula $0.5 \times a \times b \times c$ (where $a$ is the maximal longitudinal diameter, $b$ is the maximal transverse diameter perpendicular to $a$, and $c$ is the number of $10 \mathrm{~mm}$ slices from the site of infarct or hemorrhage).

All CT scans were evaluated by neuroradiologists blinded to the clinical and biochemical data.

\section{Outcome variables}

The primary endpoint was poor functional outcome defined as $\mathrm{mRS}>2$ at 90 days from onset of symptoms.

\section{Laboratory tests}

Blood samples, drawn from all patients at admission, 24 and $72 \mathrm{~h}$, were collected in test tubes, centrifuged at $3000 \mathrm{~g}$ for $10 \mathrm{~min}$, and immediately frozen and stored at $-80^{\circ} \mathrm{C}$. Serum NSE and S100 (Isoforms S100 and S100A1 $\beta$ ) concentrations were measured with an electrochemiluminescence immunoassay using the ELECSYS 2010 (Roche Diagnostics, Penzberg, Germany). This technique is based on a double sandwich assay using antibodies bound with ruthenium (luminescent label). Sensitivity of the method is $0.05 \mathrm{ng} / \mathrm{mL}$ for NSE and $0.005 \mu \mathrm{g} / \mathrm{L}$ for S100. The inter-assay variability was $4.2 \%$ for NSE and $2.4 \%$ for S100 determinations.

Determinations were performed in an independent laboratory blinded to clinical and neuroimaging data.

\section{Statistical analysis}

Results are expressed as percentages for categorical variables and as means (SD) or medians [quartiles] for continuous variables. Proportions were compared using the $\chi^{2}$ - test. Student's t-test or the Mann-Whitney test were used to compare continuous variables between groups. Spearman analysis was used for bivariate correlations.

The influence of the molecular profile of NSE and S100 protein on functional outcome was assessed using logistic regression analysis after adjusting for main baseline variables related to outcome in the univariate analyses (enter approach and probability of entry $p<0.05)$. Results were expressed as adjusted odds ratios (OR) with the corresponding $95 \%$ confidence intervals $(95 \% \mathrm{Cl})$.

\section{Results}

Baseline clinical characteristics, vascular risk factors, stroke subtype, biochemical parameters, neuroimaging findings and molecular markers in patients with IS or ICH are shown in Table 1. Poor outcomes (mRS $>2$ ) were found in $39.3 \%$ of patients with IS and in $59.1 \%$ of patients with ICH. For patients with IS, peak values were seen at $72 \mathrm{~h}$ for NSE $(10.4 \mathrm{ng} / \mathrm{mL})$ and at $24 \mathrm{~h}$ for $\mathrm{S} 100(0.15 \mu \mathrm{g} / \mathrm{L})$. However, for subjects with $\mathrm{ICH}$, peak values were seen at $24 \mathrm{~h}$ for both NSE $(13.5 \mathrm{ng} / \mathrm{mL})$ and $\mathrm{S} 100(0.13 \mu \mathrm{g} / \mathrm{L})$ (Figure 1). At these time intervals, S100 and NSE concentrations correlated with greater NIHSS scores at the same time. In fact, NSE serum concentrations correlated with NIHSS for IS at $72 \mathrm{~h}(\mathrm{r}=0.319, \mathrm{p}<0.0001)$ and at $24 \mathrm{~h}$ for ICH $(r=0.407, p<0.0001)$. Serum concentrations of S100 were associated with NIHSS for IS $(r=0.558)$ and $\mathrm{ICH}(\mathrm{r}=0.607)$ at $24 \mathrm{~h}$ (all $\mathrm{p}<0.0001)$. In addition, concentrations correlated with infarct volumes determined between the 4th and 7th days (NSE serum concentrations at $72 \mathrm{~h}$ : Spearman coefficient 0.456 , $p=0.002$; S100 serum concentrations at 24 h: Spearmen coefficient $0.714, \mathrm{p}<0.0001$ ).

Table 2 shows the temporary profile of molecular markers in patients with poor or good functional outcome in IS or $\mathrm{ICH}$. Patients with IS who had a poor outcome showed greater serum concentrations of NSE at $72 \mathrm{~h}$ and S100 at $24 \mathrm{~h}(13.7[8.2,15.9]$ vs. 8.9 $[5.3,11.6] \mathrm{ng} / \mathrm{mL} ; \mathrm{p}<0.0001)$ and $(0.28[0.12,0.46] \mathrm{vs}$. $0.11[0.07,0.28] \mu \mathrm{g} / \mathrm{L} ; \mathrm{p}<0.0001)$, respectively. Also, serum concentrations of NSE at $24 \mathrm{~h}$ were significantly greater for $\mathrm{ICH}$ patients with poor outcome compared to those with good outcome (17.8 [13.4, $21.5]$ vs. $11.6[8.1,14.2] \mathrm{ng} / \mathrm{mL} ; \mathrm{p}<0.0001)$.

After adjustment for variables that were significant in the univariate analysis, NSE at $72 \mathrm{~h}(\mathrm{OR}, 2.9 ; 95 \%$ $\mathrm{Cl}, 1.3-8.5 ; \mathrm{p}=0.032$ ) and $\mathrm{S} 100$ at $24 \mathrm{~h}$ in patients with IS were independent markers for poor outcome (OR, 4.7; 95\% Cl, 2.5-7.6; $\mathrm{p}<0.0001)$. Also, after adjustment for variables that were significant in the univariate analysis, NSE at $24 \mathrm{~h}$ in ICH was independently associated with poor outcome (OR, 2.6; $95 \% \mathrm{Cl}$, 1.9-15.6; $p=0.038$ ).

\section{Discussion}

Peripheral markers of injury to the central nervous system may help in the diagnosis and management of IS (23). This prospective study evaluates the rela- 
Table 1 Baseline clinical characteristics, vascular risk factors, stroke subtype, biochemical parameters, neuroimaging findings and molecular markers in patients with acute ischemic or hemorrhagic stroke.

\begin{tabular}{|c|c|c|}
\hline & \multicolumn{2}{|l|}{ Acute stroke } \\
\hline & $\begin{array}{l}\text { Ischemic } \\
n=224\end{array}$ & $\begin{array}{l}\text { Hemorrhagic } \\
n=44\end{array}$ \\
\hline \multicolumn{3}{|l|}{ Epidemiological variables } \\
\hline Age, years & $70.2(5.6)$ & $61.5(12.7)$ \\
\hline Male, \% & 69.6 & 59.1 \\
\hline Time from stroke onset, $\mathrm{h}$ & $7.2(4.5)$ & $4.7(2.9)$ \\
\hline History of hypertension, $\%$ & 52.2 & 60.0 \\
\hline History of diabetes, $\%$ & 17.3 & 14.8 \\
\hline History of dyslipemia, \% & 23.3 & 20.4 \\
\hline Smoking habit, \% & 15.4 & 15.0 \\
\hline \multicolumn{3}{|l|}{ Clinical characteristics } \\
\hline NIHSS at admission & $9[5,15]$ & $12[6,16]$ \\
\hline NIHSS at 1 day & $6[2,12]$ & $8[3,13]$ \\
\hline NIHSS at 3 days & $4[1,11]$ & $7[1,15]$ \\
\hline Early neurological deterioration, \% & 18.7 & 29.5 \\
\hline \multicolumn{3}{|l|}{ Stroke subtype (TOAST) } \\
\hline Atherothrombotic, \% & 13.3 & - \\
\hline Cardioembolic, \% & 37.8 & - \\
\hline Lacunar, \% & 11.0 & - \\
\hline Undetermined, \% & 34.4 & - \\
\hline Others, \% & 3.3 & - \\
\hline Dead patients in the first 3 months, $\%$ & 2.1 & 11.0 \\
\hline $\mathrm{mRS}>2$ at 3 months, $\%$ & 39.3 & 59.1 \\
\hline \multicolumn{3}{|l|}{ Neuroimaging findings } \\
\hline Infarct or ICH volume, $\mathrm{cm}^{3}$ & $18[0-54]$ & $19[10-30]$ \\
\hline \multicolumn{3}{|l|}{ Biochemistry and vital signs } \\
\hline Mean systolic blood pressure, mm Hg & $149.0(22.1)$ & $180.1(30.2)$ \\
\hline Mean diastolic blood pressure, $\mathrm{mm} \mathrm{Hg}$ & $79.2(14.6)$ & $98.1(20.3)$ \\
\hline Glucose concentration, mmol/L & $67.72[56.06-81.04]$ & 67.16 [61.61-89.37] \\
\hline \multicolumn{3}{|l|}{ Temporal profile of molecular markers } \\
\hline NSE serum concentration at admission, $\mathrm{ng} / \mathrm{mL}$ & $8.6[5.7,10.9]$ & $8.9[7.4,12.2]$ \\
\hline NSE serum concentration at $24 \mathrm{~h}, \mathrm{ng} / \mathrm{mL}$ & $9.1[6.9,10.9]$ & $13.5[9.7,15.1]$ \\
\hline NSE serum concentration at $72 \mathrm{~h}, \mathrm{ng} / \mathrm{mL}$ & $10.4[7.3,13.6]$ & $10.5[6.7,15.1]$ \\
\hline $\mathrm{S} 100$ serum concentration at admission, $\mu \mathrm{g} / \mathrm{L}$ & $0.07[0.05-0.11]$ & $0.08[0.07-0.15]$ \\
\hline S100 serum concentration at $24 \mathrm{~h}, \mu \mathrm{g} / \mathrm{L}$ & $0.15[0.07,0.32]$ & $0.13[0.06,0.27]$ \\
\hline $\mathrm{S} 100$ serum concentration at $72 \mathrm{~h}, \mu \mathrm{g} / \mathrm{L}$ & $0.06[0.04-0.16]$ & $0.12[0.09-0.23]$ \\
\hline
\end{tabular}

Data are given as percentages for categorical variables and as means (SD) or medians [quartiles] for continuous variables.

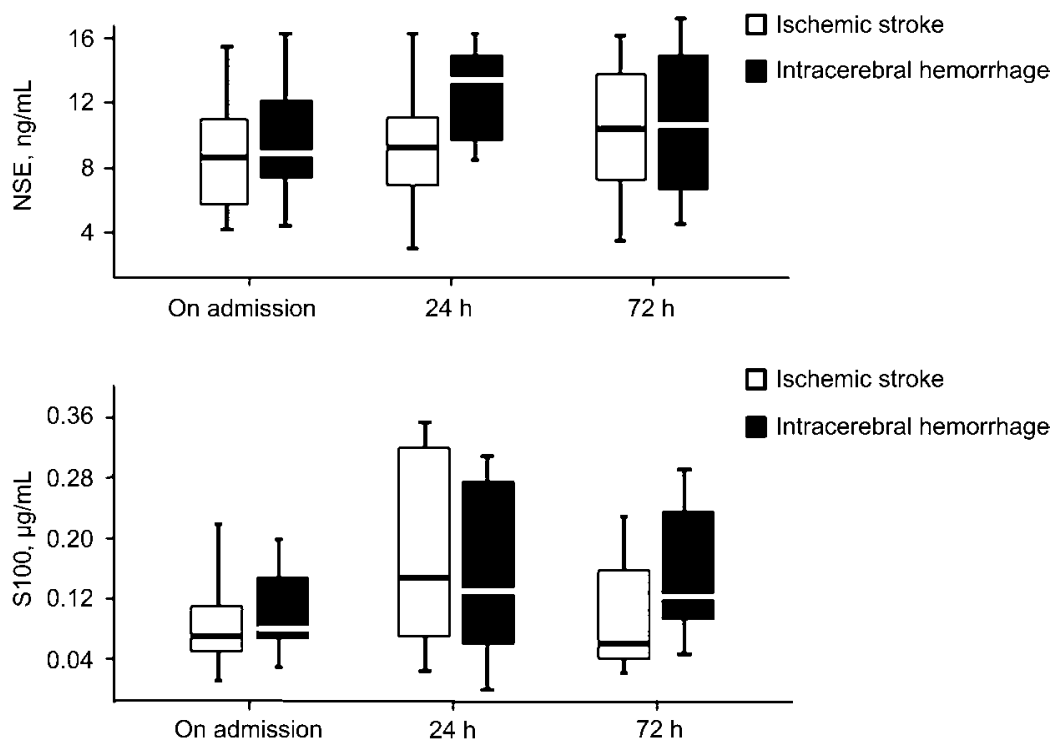

Figure 1 Temporal profile (admission, $24 \mathrm{~h}$ and $72 \mathrm{~h}$ ) of serum concentrations of NSE and S100 protein in acute ischemic and hemorrhagic stroke.

Boxplots show median values (horizontal lines inside the box), quartiles (box boundaries), and the largest and smallest observed values (lines drawn from the end of the box). 
Table 2 Temporal profile of molecular markers in patients with poor or good outcome classified in ischemic or hemorrhagic stroke.

\begin{tabular}{|c|c|c|c|}
\hline & $\begin{array}{l}\text { Good outcome } \\
(m R S \leq 2)\end{array}$ & $\begin{array}{l}\text { Poor outcome } \\
(m R S>2)\end{array}$ & p-Value \\
\hline Ischemic stroke & $\mathrm{n}=136$ & $\mathrm{n}=88$ & \\
\hline NSE serum concentration at admission & $8.5[5.2,11.9]$ & $9.2[5.3,12.1]$ & 0.067 \\
\hline NSE serum concentration at $24 \mathrm{~h}$ & $8.5[5.1,11.6]$ & $10.8[5.2,13.4]$ & 0.057 \\
\hline NSE serum concentration at $72 \mathrm{~h}$ & $8.9[5.3,11.6]$ & $13.7[8.2,15.9]$ & $<0.0001$ \\
\hline S100 serum concentration at admission & $0.06[0.05,0.12]$ & $0.08[0.05,0.15]$ & 0.064 \\
\hline S100 serum concentration at $24 \mathrm{~h}$ & $0.11[0.07,0.28]$ & $0.28[0.12,0.46]$ & $<0.0001$ \\
\hline S100 serum concentration at $72 \mathrm{~h}$ & $0.06[0.03,0.17]$ & $0.06[0.05,0.14]$ & 0.832 \\
\hline Hemorrhagic stroke & $\mathrm{n}=18$ & $\mathrm{n}=26$ & \\
\hline NSE serum concentration at admission & $7.4[6.5,10.8]$ & $9.3[7.2,13.6]$ & 0.052 \\
\hline NSE serum concentration at $24 \mathrm{~h}$ & $11.6[8.1,14.2]$ & $17.8[13.4,21.5]$ & $<0.0001$ \\
\hline NSE serum concentration at $72 \mathrm{~h}$ & $8.2[5.5,14.0]$ & $12.2[5.9,18.6]$ & 0.061 \\
\hline S100 serum concentration at admission & $0.08[0.06,0.14]$ & $0.08[0.05,0.15]$ & 0.369 \\
\hline S100 serum concentration at $24 \mathrm{~h}$ & $0.12[0.05,0.23]$ & $0.14[0.09,0.31]$ & 0.174 \\
\hline S100 serum concentration at $72 \mathrm{~h}$ & $0.06[0.02,0.21]$ & $0.07[0.02,0.30]$ & 0.805 \\
\hline
\end{tabular}

Data are given as medians [quartiles].

tionship between serum concentrations of NSE and S100 (Isoforms S100 and S100A1 $\beta$ ) and functional outcomes in patients with IS or ICH. High serum concentrations of NSE at $72 \mathrm{~h}$ and $\mathrm{S} 100$ at $24 \mathrm{~h}$ following onset of stroke were associated with poor functional outcome in patients with IS. High serum concentrations of NSE $24 \mathrm{~h}$ following onset of stroke were associated with poor functional outcome in patients with $\mathrm{ICH}$. In addition, at these time intervals we found correlation with molecular markers and infarct or hemorrhage volume.

We found that NSE at $72 \mathrm{~h}$ and $\mathrm{S} 100$ at $24 \mathrm{~h}$ for IS and NSE at $24 \mathrm{~h}$ for ICH are associated with functional outcome. Concentrations of these biomarkers at other time intervals did not show prognostic value. This demonstrates the importance of serial determinations of these biomarkers. Prognostic information is particularly relevant for estimating the risk of severe complications, and how intensive the rehabilitation program needs to be for individual patients. Several clinical scores are known to be predictive of outcome, but blood markers might also contain additional prognostic information. Because development of ischemia is a dynamic process, changes in NSE and S100 during the first $72 \mathrm{~h}$ following onset of stroke are relevant to outcome. We have demonstrated that NSE at $72 \mathrm{~h}$ and S100 at $24 \mathrm{~h}$ in patients with IS, and NSE at $24 \mathrm{~h}$ for patients with $\mathrm{ICH}$ are associated with poor functional outcome at 3 months. Thus, these biomarkers could provide additional information about the outcome of stroke patients.

The mean values of NSE in our laboratory were relatively low when compared to published cut-offs for normal values $(12.5 \mathrm{ng} / \mathrm{mL})$. It is known that measurement of NSE with the ELECSYS results in lower systematically concentrations ( $9 \%)$. However, this method presents some advantages with respect to other ELISA methods. The ELECSYS has a low intraand interassay coefficient of variation $(0.7 \%-5.3 \%)$, reportable range between 0.0 and $320 \mathrm{ng} / \mathrm{mL}$ and a short incubation time of $18 \mathrm{~min}$ (24). In addition, in the study by Wunderlich et al. (19), the concentrations of NSE assessed with the LIAISON kit (DiaSorin, Diag- nostica, Dietenzbach, Germany) exceeded the cut-off value of $12.5 \mathrm{ng} / \mathrm{mL}$ in $13 \%$ of stroke patients only, during the first $24 \mathrm{~h}$.

Comparing the association of these molecular markers with functional outcome, we found that similar studies conducted by Jauch et al. (25) on patients with acute IS showed that the strongest correlation between NSE and S100 concentrations and outcome was seen in samples drawn within $24 \mathrm{~h}$ from onset of stroke. Likewise, our results are in agreement with those reported by Martens et al. (26) who used serum concentrations of $\mathrm{S} 100$ protein at $24 \mathrm{~h}$ as a marker for cerebral damage in patients affected with global cerebral ischemia. However, our finding contrasts with the study of Cunningham et al. (27) who reported correlation between NSE concentrations and infarct volume, but not with outcome. This study evaluated a total of 24 patients only, which might explain the lack of an association with outcome. Other studies have found a correlation between S100 concentrations and outcome in patients with subarachnoid hemorrhage $(28,29)$.

The analysis of the expression profile of these proteins revealed that the highest concentrations for NSE and for S100 were seen at $24 \mathrm{~h}$ in patients with $\mathrm{ICH}$, whereas, patients with IS showed highest concentrations of NSE and S100 at $72 \mathrm{~h}$ and $24 \mathrm{~h}$, respectively. These results are in agreement with previous studies that show a peak value at $24 \mathrm{~h}$ for NSE concentrations in patients with IS, as well as those treated with tissue plasminogen activator (tPA) (30). However, other investigators report peak concentrations $2-3$ or more days following onset $(17,30,31)$.

In this prospective study, we analyzed the relationship between serum concentrations of NSE and S100 proteins with neurological and functional outcomes in more than 200 patients with IS and more than 40 patients with $\mathrm{ICH}$. Other studies have been carried out using different evaluation scales for functional outcome, such as the Glasgow Outcome Score, studying shorter evolution times, differentiating the infarcts by territories and using smaller number of patients. These variables may explain why many of the results 
reported previously could be different with those reported in our study (32).

In summary, high serum concentrations of NSE at $72 \mathrm{~h}$ and $\mathrm{S} 100$ at $24 \mathrm{~h}$ following stroke are associated with poor outcome in patients with IS. High serum concentrations of NSE at $24 \mathrm{~h}$ following stroke are associated with poor outcome in patients with $\mathrm{ICH}$. These findings suggest the potential prognostic utility of these markers for acute stroke.

\section{Conflict of interest statement}

The authors state that they have not accepted any funding or support from an organization that may in any way gain or lose financially from the results of our study. We have not been employed by an organization that may in any way gain or lose financially from the results of our study and we do not have any other conflicting interests.

\section{Acknowledgements}

Partial results of this investigation were presented at the 15th European Stroke Conference in Brussels, Belgium (May 2006). This project has been partially supported by grants from the Spanish Ministry of Health (Instituto de Salud CarIos III) RETICS-RD06/0026; Xunta de Galicia (Consellería de Innovación, Industria e Comercio) PGIDIT06PXIB918316PR and PGIDIT05SAN29PR, and the Consellería de Educación e Ordenación Universitaria of Xunta de Galicia (Axudas para a Consolidación e Estruturación de Unidades de Investigación Competitivas. Expediente: 80/2006); and Fundación de Investigación Médica Mútua Madrileña. Furthermore, D. Brea and R. Rodríguez-González are a recipients of fellowships funded by Carlos III Institute of Health from Spain (Ayudas predoctorales de formación en investigación).

\section{References}

1. Castillo J, Dávalos A, Naveiro J, Noya M. Neuroexcitatory amino acids and their relation to infarct size and neurological deficit in ischemic stroke. Stroke 1996;27:1060-5.

2. Castillo J, Leira R. Predictors of deteriorating cerebral infarct: role of inflammatory mechanisms. Would its early treatment be useful? Cerebrovasc Dis 2001;11:40-8.

3. Castellanos M, Castillo J, García MM, Leira R, Serena J, Chamorro A, et al. Inflammation-mediated damage in progressing lacunar infarctions a potential therapeutic target. Stroke 2002;33:982-7.

4. Castillo J, Dávalos A, Noya M. Progression of ischaemic stroke and excitotoxic aminoacids. Lancet 1997;349:7983.

5. Castellanos M, Leira R, Serena J, Blanco M, Pedraza S, Castillo J, et al. Plasma cellular-fibronectin concentration predicts hemorrhagic transformation after thrombolytic therapy in acute ischemic stroke. Stroke 2004;35:1671-6.

6. Castellanos M, Leira R, Serena J, Pumar JM, Lizasoain I, Castillo J, et al. Plasma metalloproteinase-9 concentration predicts hemorrhagic transformation in acute ischemic stroke. Stroke 2003;34:40-5.

7. Schafer BW, Fritschy JM, Murmann P, Troxler H, Durussel I, Heizmann CW, et al. Brain S100A5 is a novel calcium-, zinc-, and copper ion-binding protein of the EF-hand superfamily. J Biol Chem 2000;275:30623-30.

8. Zimmer DB, Cornwall EH, Reynolds PD, Donald CM. S100A1 regulates neurite organization, tubulin levels, and proliferation in PC12 cells. J Biol Chem 1998;273: 4705-11.

9. Zimmer DB, Cornwall EH, Landar A, Song W. The S100 protein family: history, function, and expression. Brain Res Bull 1995;37:417-29.

10. Barone FC, Clark RK, Price WJ, White RF, Feuerstein GZ, Storer $\mathrm{BL}$, et al. Neuron-specific enolase increases in cerebral and systemic circulation following focal ischemia. Brain Res 1993;623:77-82.

11. Marchi N, Rasmussen P, Kapural M, Fazio V, Kight K, Mayberg MR, et al. Peripheral markers of brain damage and blood-brain barrier dysfunction. Res Neurol Neurosci 2003;21:109-21.

12. Nash DL, Bellolio MF, Stead LG. S100 as a marker of acute brain ischemia: a systematic review. Neurocrit Care 2008;8:301-7.

13. Foerch C, Singer OC, Neumann-Haefelin T, du Mesnil de Rochemont R, Steinmetz H, Sitzer M. Evaluation of serum $\mathrm{S} 100 \mathrm{~B}$ as a surrogate marker for long-term outcome and infarct volume in acute middle cerebral artery infarction. Arch Neurol 2005;62:1130-4.

14. Jauch EC, Lindsell C, Broderick J, Fagan SC, Tilley BC, Levine SR. Association of serial biochemical markers with acute ischemic stroke: the National Institute of Neurological Disorders and Stroke recombinant tissue plasminogen activator Stroke Study. Stroke 2006;37: 2508-13.

15. Petzold A, Michel P, Stock M, Schluep M. Glial and axonal body fluid biomarkers are related to infarct volume, severity, and outcome. J Stroke Cerebrovasc Dis 2008; 17:196-203.

16. Sienkiewicz-Jarosz $H$, Galecka-Wolska M, Bidzinski A, Turzynska D, Sobolewska A, Lipska B, et al. Predictive value of selected biochemical markers of brain damage for functional outcome in ischaemic stroke patients. Neurol Neurochir Pol 2009;43:126-33.

17. Wunderlich MT, Ebert AD, Kratz T, Goertler M, Jost $S$, Herrmann M. Early neurobehavioral outcome after stroke is related to release of neurobiochemical markers of brain damage. Stroke 1999;30:1190-5.

18. Geiger $S$, Holdenrieder $S$, Stieber $P$, Hamann GF, Bruening $\mathrm{R}, \mathrm{Ma} \mathrm{J}$, et al. Nucleosomes as a new prognostic marker in early cerebral stroke. J Neurol 2007;254: 617-23.

19. Wunderlich MT, Lins H, Skalej M, Wallesch CW, Goertler M. Neuron-specific enolase and tau protein as neurobiochemical markers of neuronal damage are related to early clinical course and long-term outcome in acute ischemic stroke. Clin Neurol Neurosurg 2006;108:55863.

20. Comité ad hoc del Grupo de Estudio de Enfermedades Cerebrovasculares de la SEN. Guía para el diagnóstico y tratamiento del ictus. Prous Science. Barcelona 2004.

21. Bessenyei M, Fekete I, Csiba L, Bereczki D. Characteristics of 4 stroke scales for the detection of changes in clinical signs in the acute phase of stroke. J Stroke Cerebrovasc Dis 2001;10:70-8.

22. Lyden PD, Hantson L. Assessment scales for the evaluation of stroke patients. J Stroke Cerebrovasc Dis 1998; 7:113-27.

23. Reynolds MA, Kirchick HJ, Dahlen JR, Anderberg JM, McPherson PH, Nakamura KK, et al. Early biomarkers of stroke. Clin Chem 2003;49:1733-9.

24. Muley T, Ebert W, Stieber P, Raith $H$, Holdenrieder S, Nagel $D$, et al. Technical performance and diagnostic utility of the new Elecsys neuron-specific enolase enzyme immunoassay. Clin Chem Lab Med 2003;41:95103.

25. Jauch EC, Lindsell C, Broderick J, Fagan SC, Tilley BC, Levine SR, for the Nr-PASSG. Association of serial biochemical markers with acute ischemic stroke: the National Institute of Neurological Disorders and Stroke 
Recombinant Tissue Plasminogen Activator Stroke Study. Stroke 2006;37:2508-13.

26. Martens P, Raabe A, Johnsson P. Serum S-100 and neuron-specific enolase for prediction of regaining consciousness after global cerebral ischemia. Stroke 1998;29:2363-6.

27. Cunningham RT, Young IS, Winder J, O'Kane MJ, McKinstry S, Johnston CF, et al. Serum neurone specific enolase (NSE) levels as an indicator of neuronal damage in patients with cerebral infarction. Eur J Clin Invest 1991;21:497-500.

28. Oertel M, Schumacher U, McArthur DL, Kastner S, Boker D-K. S-100B and NSE: markers of initial impact of subarachnoid haemorrhage and their relation to vasospasm and outcome. J Clin Neurosci 2006;13:834-40.

29. Delgado P, Alvaroz Sabin J, Santamarina E, Molina CA,
Quintana M, Rosell A, et al. Plasma S100B level after acute spontaneous intracerebral hemorrhage. Stroke 2006;37:2837-9.

30. Anand N, Stead LG. Neuron-specific enolase as a marker for acute ischemic stroke: a systematic review. Cerebrovasc Dis 2005;20:213-9.

31. Fassbender K, Schmidt R, Schreiner A, Fatar M, Muhlhauser F, Daffertshofer M, et al. Leakage of brain-originated proteins in peripheral blood: temporal profile and diagnostic value in early ischemic stroke. J Neurol Sci 1997;148:101-5.

32. Wunderlich MT, Wallesch C-W, Goertler M. Release of neurobiochemical markers of brain damage is related to the neurovascular status on admission and the site of arterial occlusion in acute ischemic stroke. J Neurol Sci 2004:227:49-53. 